\title{
Screening of Twelve Pea (Pisum sativum L.) Cultivars and Their Isolates Focusing on the Protein Characterization, Functionality, and Sensory Profiles
}

\author{
Verónica García Arteaga 1,2,*iD, Sonja Kraus ${ }^{1}$, Michael Schott ${ }^{1}$, Isabel Muranyi ${ }^{1}$, Ute Schweiggert-Weisz ${ }^{1,3}$ \\ and Peter Eisner 1,4,5
}

Citation: García Arteaga, V.; Kraus, S.; Schott, M.; Muranyi, I.; Schweiggert-Weisz, U.; Eisner, P. Screening of Twelve Pea (Pisum sativum L.) Cultivars and Their Isolates Focusing on the Protein Characterization, Functionality, and Sensory Profiles. Foods 2021, 10, 758 https://doi.org/10.3390/

foods10040758

Academic Editors: Christine Scaman and Joana S. Amaral

Received: 4 March 2021

Accepted: 30 March 2021

Published: 2 April 2021

Publisher's Note: MDPI stays neutral with regard to jurisdictional claims in published maps and institutional affiliations.

Copyright: (c) 2021 by the authors. Licensee MDPI, Basel, Switzerland. This article is an open access article distributed under the terms and conditions of the Creative Commons Attribution (CC BY) license (https:// creativecommons.org/licenses/by/ $4.0 /)$
1 Fraunhofer Institute for Process Engineering and Packaging IVV, 85354 Freising, Germany; sonni.kraus@gmail.com (S.K.); michael.schott@ivv.fraunhofer.de (M.S.); isabel.muranyi@ivv.fraunhofer.de (I.M.); uweisz@uni-bonn.de (U.S.-W.); peter.eisner@ivv.fraunhofer.de (P.E.) 2 Center of Life and Food Sciences Weihenstephan, Technical University of Munich, 85354 Freising, Germany Institute for Nutritional and Food Sciences, University of Bonn, 53012 Bonn, Germany

ZIEL-Institute for Food \& Health, Technical University of Munich, 85354 Freising, Germany

School of Technology and Engineering, Steinbeis-Hochschule, 12489 Berlin, Germany

* Correspondence: veronica.garcia.arteaga@ivv.fraunhofer.de; Tel.: +49-8161-491-465

Abstract: Pea protein concentrates and isolates are important raw materials for the production of plant-based food products. To select suitable peas (Pisum sativum L.) for protein extraction for further use as food ingredients, twelve different cultivars were subjected to isoelectric precipitation and spray drying. Both the dehulled pea flours and protein isolates were characterized regarding their chemical composition and the isolates were analyzed for their functional properties, sensory profiles, and molecular weight distributions. Orchestra, Florida, Dolores, and RLPY cultivars showed the highest protein yields. The electrophoretic profiles were similar, indicating the presence of all main pea allergens in all isolates. The colors of the isolates were significantly different regarding lightness $\left(\mathrm{L}^{*}\right)$ and red-green $\left(\mathrm{a}^{*}\right)$ components. The largest particle size was shown by the isolate from Florida cultivar, whereas the lowest was from the RLPY isolate. At $\mathrm{pH} 7$, protein solubility ranged from $40 \%$ to $62 \%$ and the emulsifying capacity ranged from 600 to $835 \mathrm{~mL} \mathrm{~g}^{-1}$. The principal component analysis revealed similarities among certain pea cultivars regarding their physicochemical and functional properties. The sensory profile of the individual isolates was rather similar, with an exception of the pea-like and bitter attributes, which were significantly different among the isolates.

Keywords: pea (Pisum sativum L.); spray-dry; functional properties; sensory profile; protein characterization; pea allergens

\section{Introduction}

Peas (Pisum sativum L.) were domesticated around 10,000 years ago. Over the years, evolution and breeding has influenced the number of pea cultivars found today. In Europe, according to the Food and Agriculture Organization database [1], France and Germany were the biggest dry pea seed producers in 2019. The differences among cultivars depend on their cultivated status (wild or cultivated), geographical origin, and usage (fresh or dry) [2]. The study of different cultivars, their breeding, and their inclusion in the genome database is a continuous process [3]. From an agronomic point of view, cultivation factors such as maximum yield security, plant stability, seed percentage, and protein yield are the most important characteristics considered for pea cultivation; however, for industrial food production, factors such as protein content, functionality, taste, and color are also considered [4]. Peas contain high amounts of protein at around 20-35\%, low amounts of fat at around $0.5-4.0 \%$, and high amounts of starch at around 30-48\% [5-7]. Previous studies have investigated the differences in pea cultivar compositions and have found environmental and genotypic variations as the main factors for the described data discrepancies. 
The aroma of the pea seeds also changes significantly depending on the cultivar, harvest year, and processing conditions $[8,9]$.

Vegetarian or vegan diets might lead to protein deficiencies, making peas an interesting protein source for plant-based food products [10]. According to the Global Market Insights report [11], the pea protein market is estimated to grow by $12 \%$ compound annual growth rate (CAGR) by 2026. The main proteins in peas correspond to storage proteins. These are divided into globulins and albumins, corresponding to $55-80 \%$ and $18-25 \%$, respectively, depending on genetic and environmental factors $[6,12,13]$. Similar to other legumes, the major globulins in peas are divided into $7 \mathrm{~S}$ vicilin-convicilin and $11 \mathrm{~S}$ legumin fractions [14]. The molecular structures and weight distributions are different among these proteins. Legumin is a hexamer with major polypeptide subunits of $\sim 40$ and $\sim 20 \mathrm{kDa}$, which can be bound by disulfide bonds. Vicilin is a trimer (each subunit $\sim 50 \mathrm{kDa}$ ) lacking cysteine residues that can undergo post-translational proteolysis, resulting in different fractions. Convicilin is a trimer $(\sim 70 \mathrm{kDa})$ without any translational modification $[15,16]$.

Pea proteins are used as concentrates ( $40-90 \%$ protein) and isolates ( $>90 \%$ protein) in the food industry; however, the extraction of pea protein isolate (PPIs) at laboratory and pilot scales has shown protein contents of around 80-90\% [17-19]. These studies have found that depending on the cultivar and the extraction method, the protein solubility and emulsifying and foaming capacity were significantly affected; however, Stone and Karalash [17] concluded that overall, the extraction method has a greater influence than the cultivar. The PPIs investigated in the above-mentioned studies showed higher functionality than commercial isolates. This could be due to a deviating production or drying process. Industrial protein ingredient suppliers usually use spray drying, whereas lyophilization is mainly used for scientific purposes at the laboratory scale. Spray drying might affect the aroma and protein structure, and thus the protein profile, particle size, and functionality $[9,20]$. Moreover, most authors have investigated cultivars available in their countries. In Germany, the cultivars Astronaute and Salamanca are mainly used because of their high seed yields [21]; however, to our knowledge, only protein preparations of the latter cultivar have been characterized scientifically [22]. A broader screening of European pea cultivars would increase the ability to select a cultivar that fulfills specific product needs.

Another reason for the high popularity of peas as raw materials for protein isolation is that unlike soy, pea proteins do not need to be declared as allergens in Europe. However, two major allergens, namely convicilin (Pis s 2) and vicilin (Pis s 1), have been identified [23]. Pis $\mathrm{s} 2$ corresponds to a $62-67 \mathrm{kDa}$ fraction, whereas Pis s 1 corresponds to $47-50 \mathrm{kDa}$ (mature vicilin- $\alpha \beta \gamma$ ) and $32 \mathrm{kDa}($ vicilin- $\alpha \beta)$ fractions. These allergens could potentially promote cross-reactions with other legume allergens; thus, recent studies suggest their inclusion in the allergen declaration list $[24,25]$. The allergenic potential might vary within and among cultivars, as they have shown significant proteomic variations of the same pea cultivar harvested over three consecutive years [16].

The present study aimed to investigate pea cultivars grown in Germany and France, regarding chemical compositions of their flours and isolates, as well as the protein yields, functional properties, aroma profiles, and molecular weight distribution of the PPIs. Among the data assessed, this study aimed to identify PPIs of cultivars showing similar chemical, functional, and sensory properties in order to use them in combination or interchangeably in the food industry, without having significant effects on the final product quality.

\section{Materials and Methods}

\subsection{Materials}

The different field pea seeds (Pisum sativum L.) were kindly provided by Norddeutsche Pflanzenzucht Hans-Georg-Lembke KG (Holtsee, Germany) and are shown in Table 1. The Broad Range ${ }^{\mathrm{TM}}$ Unstained Standard, 4-20\% Criterion $^{\mathrm{TM}}$ TGX Stain-Free ${ }^{\mathrm{TM}}$ Precast Gels, and Coomassie blue R-250 were purchased from Bio-Rad Laboratories GmbH (Feldkirchen, Germany). Sodium dihydrogen phosphate, sodium dodecyl sulfate, and sodium monohy- 
drogen phosphate were purchased from Sigma-Aldrich Chemie GmbH (Munich, Germany).

All chemicals used in this study were of analytical grade.

Table 1. List of pea cultivars investigated in this study.

\begin{tabular}{ccccc}
\hline Cultivar & Harvest Year & Place of Cultivation & Cotyledon Color & Admitted in \\
\hline Navarro & 2018 & Malchow/Mecklenburg-Vorpommern & yellow & Germany \\
\hline Dolores & 2015 & Oderaue/Mecklenburg-Vorpommern & yellow & Germany \\
\hline Greenwich & 2018 & Hohenlieth/Schleswig-Holstein & green & Great Britain \\
\hline Bluetime & 2018 & Hohenlieth/Schleswig-Holstein & green & Great Britain \\
\hline Ostinato & 2018 & Rodez/France & yellow & France \\
\hline Kalifa & 2017 & Hohenlieth/Schleswig-Holstein & yellow & Breeding line \\
\hline Salamanca & 2018 & Malchow/Mecklenburg-Vorpommern & yellow & Germany, Czech \\
\hline Florida & 2015 & Dreveskirchen/Mecklenburg-Vorpommern & yellow & Germany \\
\hline RLPY141091 & 2018 & Rodez/France & yellow & Germany \\
\hline Orchestra & 2018 & Rodez/France & yellow & France, Germany \\
\hline Astronaute & 2018 & Groß Kiesow/Mecklenburg-Vorpommern & yellow & France, Germany, etc. \\
\hline Croft & 2018 & Hohenlieth/Schleswig-Holstein & green & Great Britain \\
\hline
\end{tabular}

\subsection{Production of Pea Flour}

Peas were dehulled and split using an underflow peeler (Streckel and Schrader KG, Hamburg, Germany). The kernels were separated using a zig-zag airlift system and milled with a pilot plant impact mill with $0.5 \mathrm{~mm}$ sieve insertion (Alpine Hoakawa AG, Augsburg, Germany).

\subsection{Production of Pea Protein Isolate}

The isolation of pea protein was performed according to Tian and Kyle [26] following an alkaline extraction with isoelectric precipitation (AE-IEP) with some changes. An aqueous alkaline extract of the pea flour was prepared in deionized (DI) water at a ratio of 1:5 $(w / w)$ at $\mathrm{pH} 8.0$ using $3.0 \mathrm{~mol} / \mathrm{L} \mathrm{NaOH}$, which was stirred for $60 \mathrm{~min}$. The protein extract was sieved $(0.8 \mathrm{~mm})$ after centrifugation at $8000 \times g$ for $20 \mathrm{~min}$ at $15^{\circ} \mathrm{C}(8 \mathrm{~K}$, Sigma Laborzentrifugen $\mathrm{GmbH}$, Osterode am Harz, Germany). For isoelectric precipitation, the protein extract was adjusted to $\mathrm{pH} 4.5$ using $3.0 \mathrm{~mol} / \mathrm{L} \mathrm{HCl}$ and left overnight at $4{ }^{\circ} \mathrm{C}$. The precipitated proteins were separated by centrifugation at $8000 \times g$ for $20 \mathrm{~min}$ at $15^{\circ} \mathrm{C}$ and the protein isolate was dispersed in DI water to a dry matter content of $8 \%$. After neutralization to $\mathrm{pH}$ 7.0, the isolate dispersion was homogenized at 11,000 rpm for $2 \mathrm{~min}$ using an Ultraturrax $\left(\mathrm{IKA}^{\circledR}\right.$-Werke $\mathrm{GmbH}$ and Co. KG, Staufen, Germany) prior to spray drying. The spray drying was performed using a Mini Spray Dryer B-191 (BUCHI Labortechnik GmbH, Essen, Germany) at inlet and outlet temperatures of $180^{\circ} \mathrm{C}$ and $80^{\circ} \mathrm{C}$, respectively, as well as with a $95 \%$ aspirator output. The spray-dried isolates were used for further analysis. The protein yield was calculated as grams of protein per kilogram of seeds. Due to the limited amounts of pea seeds, the protein extractions and spray drying were performed once. We assumed that the protein extraction and yield values are representative of the process, as other studies have shown low standard deviations in their own extractions $[17,18]$.

\subsection{Chemical Composition}

The analysis of the chemical compositions of the pea flours and PPIs included determination of the dry matter, ash, protein, starch, and fat contents.

Dry matter and ash contents were determined using thermogravimetric methods (TGA 701, Leco Instruments, Mönchengladbach, Germany). The protein content was determined according to the Dumas combustion method (TruMac N, Leco Instruments, Mönchenglad- 
bach, Germany) using the average nitrogen-to-protein conversion factor of $\mathrm{N} \times 6.25$. All analyses were performed in duplicate and in accordance with the Association of Official Analytical Collaboration (AOAC) Official Methods [27,28].

The starch content was determined in duplicate using a Starch UV-Test Kit according to the manufacturer's instructions (R-Biopharm AG, Darmstadt, Germany). The fat content was determined according to the Caviezel method [29] with some modifications. In extraction vessels, 2-3 g of the sample was mixed with $1.5 \mathrm{~g}$ potassium hydroxide, $5 \mathrm{~mL}$ stock solution, and $40 \mathrm{~mL}$ 1-butanol. After separation of the derivatized fatty acids by gas chromatography (GC 7890A, Agilent Technologies Germany GmbH \& Co. KG, Waldbronn, Germany), the total fat content was determined by summing up all detected methyl esters in relation to an internal standard. Mazola corn germ oil served as the reference. The results are given in fat $\%$, calculated as methyl ester.

\subsection{Molecular Weight Distribution Using Sodium Dodecyl Sulfate-Polyacrylamide Gel Electrophoresis (SDS-PAGE)}

The molecular weight distribution was analyzed using SDS-PAGE under non-reducing and reducing conditions according to the method used by Laemmli [30], with slight modifications. Briefly, $5 \mu \mathrm{g} / \mu \mathrm{L}$ protein solution (based on dry matter) was prepared in $1 \times$ treatment buffer $(50 \%(v / v) 2 \times$ Tris- $\mathrm{HCl}$ treatment buffer, $50 \%(v / v)$ phosphate buffer $(\mathrm{pH} 7)$ ). The $2 \times$ treatment buffer was prepared using $0.125 \mathrm{M}$ from the $4 \times$ stacking gel buffer (0.5M Tris, adjusted with $\mathrm{HCl}$ to $\mathrm{pH} 6.8$ ), $4 \%$ from $10 \%$ SDS, $20 \%$ glycerol, and $0.02 \%$ Bromophenol Blue, while for reduction conditions $0.2 \mathrm{M}$ dithiothreitol was added. The samples were heated $\left(95^{\circ} \mathrm{C}, 5 \mathrm{~min}\right.$ ) prior to centrifugation at $12,045 \times \mathrm{g}$ for $3 \mathrm{~min}$ (MiniSpin, Eppendorf AG, Hamburg, Germany). The supernatants were mixed 1:10 $(v / v)$ with $1 \times$ treatment buffer, from which $3 \mu \mathrm{L}$ was added into the gel pocket of the Bio-Rad $4-20 \%$ Criterion $^{\mathrm{TM}}$ TGX Stain-Free ${ }^{\mathrm{TM}}$ Precast Gels. The Broad Range ${ }^{\mathrm{TM}}$ Unstained Protein Standard was used as the molecular weight marker. The running time was $30 \mathrm{~min}$, followed by staining using Coomassie Brilliant Blue R-250. Finally, gel images were obtained using an EZ Imager (Gel Doc ${ }^{\mathrm{TM}}$ EZ Imager-Bio-Rad). Protein bands and their intensities were calculated using Image Lab Software. SDS-PAGE was performed in duplicate, with each sample being prepared two times independently.

\subsection{Color}

The colors of the protein isolates were measured using the Digi Eye system (VeriVide Limited, Leicester, UK) and a Nikon D90 camera (Nikon Metrology GmbH, Düsseldorf, Germany). The International Commission on Illumination (CIE) $\mathrm{L}^{*} \mathrm{a}^{*} \mathrm{~b}^{*}$ method was used to measure the parameters lightness $\left(\mathrm{L}^{*}\right)$, green-red $\left(\mathrm{a}^{*}\right)$, and blue-yellow $\left(\mathrm{b}^{*}\right)$. The white color from the calibration board was used as the white reference for comparison among samples. The total color difference $\left(\Delta E_{a b}^{*}\right)$ compared to the white reference board was calculated according to the CIE76 formula (Equation (1)). The color determination was performed in triplicate.

$$
\Delta E_{a b}^{*}=\sqrt{\left(L_{2}^{*}-L_{1}^{*}\right)^{2}+\left(a_{2}^{*}-a_{1}^{*}\right)^{2}+\left(b_{2}^{*}-b_{1}^{*}\right)^{2}}
$$

\subsection{Particle Size}

The particle size distribution of all pea protein isolates was determined using a MasterSizer S Long Bed Version 2.19 equipped with a QS Small Volume Sample Dispersing Unit DIF2021 (Malvern Panalytical Ltd., Malvern, UK). The sample was dispersed in 1-Butanol for $2 \mathrm{~min}$ at $3000 \mathrm{rpm}$ before measurements. After another minute, a second measurement was conducted. The measuring range was set at $300 \mathrm{RF} 0.05-900 \mu \mathrm{m}$. The particle size was based on Mie theory with a refractive index of 1.33, using an index of 0.1 for dispersion media and 1.56 for the dispersed phase, with an imaginary proportion of 0.1 . 


\subsection{Functional Properties}

All analyses of functional properties were performed in duplicate.

\subsubsection{Protein Solubility}

The protein solubility measurements at $\mathrm{pH} 4.5$ and 7.0, respectively, were performed according to Morr and German [31]. The soluble protein content was determined photometrically at $550 \mathrm{~nm}$ following the Biuret method [32] using bovine serum albumin (BSA) as the standard for calibration.

\subsubsection{Foaming Capacity}

The foaming capacity was analyzed at $\mathrm{pH} 4.5$ and 7.0 according to Phillips and Haque [33] using a whipping machine (Hobart N50, Hobart GmbH, Offenburg, Germany). Briefly, $5 \%(w / v)$ dispersions were whipped $(580 \mathrm{rpm})$ for $8 \mathrm{~min}$ and the foaming capacities were determined as the relation between the initial and final volume.

\subsubsection{Emulsifying Capacity}

The emulsifying capacity was determined according to Wang and Johnson [34] and García Arteaga, et al. [35] at $\mathrm{pH} 4.5$ and 7.0. Briefly, $10 \mathrm{~mL} \mathrm{~min}^{-1}$ oil was added to a dispersion $(1 \% w / w)$ in a $1 \mathrm{~L}$ reactor equipped with an Ultra-Turrax instrument and a conductivity meter. The volume of added oil was used to calculate the emulsifying capacity (mL oil/g sample).

\subsection{Sensory Analysis}

\subsubsection{Sample Preparation}

A $2 \%$ sample solution $(1.7 \%$ protein, $w / w)$ was prepared with tap water for each PPI. The respective samples were adjusted to $\mathrm{pH} 7.0$ with $1 \mathrm{~mol} / \mathrm{L} \mathrm{NaOH}$ and coded using three-digit random numbers.

\subsubsection{Sample Evaluation}

The sensory evaluation was conducted according to DIN 10967-1-1999 and as described by García Arteaga, et al. [35]. Briefly, a trained panel evaluated attributes regarding retronasal aromas and tastes of the different PPIs. From each sample solution, $20 \mathrm{~mL}$ was presented at room temperature in a glass cup and in random order. The sensory evaluation was split into two evaluation sessions. In the evaluation sessions, each panelist evaluated six and seven samples, respectively. The panelists assessed the samples according to the following attributes: fatty (2-nonenal); green (hexanal); earthy (geosmin); roasty (2-acetylpyrazine); pea-like (2-isopropyl-3-methoxypyrazine); metallic ((trans)-4,5-Epoxy-(E)decenal); malty; nutty (2,5-dimethylpyrazine). Additionally, panelists assessed the samples according to tastes such as bitter, sweet, salty, astringent, mouth-coating, and overall intensity. The intensities were scored from 0 (not perceivable) to 10 (very intense).

\subsection{Principal Component Analysis}

A principal component analysis (PCA) is a multivariate statistical data analysis tool used to simplify the variability of data with a reduced number of dependent variables. A PCA (correlation matrix) was used to evaluate the similarities among isolates regarding their protein content, fat content, color, particle size, and functional properties. A covariance PCA was used to evaluate the aroma and taste. The PCA plots were performed using the software OriginPro 2018b.

\subsection{Statistical Analysis}

Protein extractions were performed once and the resulting isolates were used for further analyses. Due to the low protein yields, all analyses were performed in duplicate, unless stated otherwise, and the results are expressed as mean values \pm standard deviations. Non-parametric statistical analyses were performed due to the low number 
of replicates. The Kruskal-Wallis test was used to determine statistical differences among the cultivars. Dunn's test with Bonferroni correction for $p$-values was used as a test for multiple comparisons. The results of the sensory analysis were analyzed using one-way ANOVA followed by Tukey's post hoc test. A Kendall correlation coefficient was used to determine correlations between physicochemical, functional, and sensory properties. All statistical analyses were performed using OriginPro $2018 \mathrm{~b}$ and were considered statistically significant at $p<0.05$. The raw data are available as Mendeley Data [36].

\section{Results and Discussion}

\subsection{Chemical Composition and Protein Yield}

Table 2 shows the chemical compositions of the flours and PPIs, as well as the protein yields after spray drying.

\subsubsection{Pea Flours}

The protein contents of the dehulled pea flours ranged from $21.3 \%$ to $27.2 \%$, similar to values obtained by Barac and Cabrilo [18] and Nikolopoulou and Grigorakis [6]. The flour from RLPY cultivar showed the highest protein content $(27.2 \%)$, whereas the flour from Greenwich had the lowest protein content at $21.3 \%$. The ash and fat contents ranged from $2.5 \%$ to $3.6 \%$ and from $1.9 \%$ to $2.5 \%$, respectively. The flour from the Florida cultivar showed the highest fat content of $2.7 \%$, whereas the flours of Dolores, Ostinato, Kalifa, RLPY, and Orchestra cultivars showed the lowest amounts at 1.9\%. The flour from Navarro had the highest starch content, while RLPY had the lowest. The protein and starch contents obtained in this study were within the ranges of different cultivars investigated in other studies [22,37].

\subsubsection{Pea Protein Isolates}

The protein contents of the pea protein isolates (PPIs) ranged from $83.5 \%$ to $90.3 \%$. The PPI obtained from the RLPY cultivar showed the highest protein content, while the one from Navarro showed the lowest. The protein contents were in the same range as in other studies $[17,18]$; however, other studies obtained higher protein yields $(62-89 \%)$, probably attributed to the drying technique, as high losses are common during spray drying [38]. It is worth mentioning that protein isolation at industrial scale might result in higher yields when the drying kinetics are correctly determined [39,40]. The highest protein yield was $62.2 \mathrm{~g}$ protein $\mathrm{kg}^{-1}$ seed $^{-1}$ obtained from the Orchestra cultivar, followed by Florida with $59.2 \mathrm{~g} \mathrm{~kg}^{-1}$. The lowest protein yields were obtained from Navarro and Greenwich cultivars at $33.8 \mathrm{~g} \mathrm{~kg}^{-1}$ and $34.8 \mathrm{~g} \mathrm{~kg}^{-1}$, respectively. The ash contents of the PPIs varied from $5.3 \%$ to $8.5 \%$, probably due to formation of salts $(\mathrm{NaCl})$ after adjusting the $\mathrm{pH}$ during the different process steps. The fat contents ranged from $4.7 \%$ to $9.0 \%$, with the Greenwich isolate having the highest fat content and Dolores isolate the lowest. The PPIs without a de-fatting step had higher lipid contents, probably due to the protein-lipid interactions during the extraction; Gao and Shen [41] showed that PPIs extracted after AE-IEP had predominantly hydrophobic $\beta$-sheets in their protein structures that could promote these interactions [42]. Furthermore, the increase in fat content might promote lipid-protein interactions in the isolates, which may lead to a higher hydrophobic character of the complexes, resulting in lower protein solubility. Their interaction may also reduce the availability of lipophilic groups, limiting the absorption of fat [43]. The color, aroma, and functionality might be also affected by the fat content, especially after lipid oxidation by lipoxygenase [44]. 
Table 2. Chemical composition and protein yield of dehulled flour and protein isolates produced from different pea cultivars.

\begin{tabular}{|c|c|c|c|c|c|c|}
\hline Cultivar & Dry Matter & Protein * & Ash 550 * & Fat* & Starch * & Protein Yield ** \\
\hline & {$[\%]$} & [\%] & [\%] & [\%] & [\%] & {$\left[\mathrm{g} \mathrm{kg}^{-1}\right]$} \\
\hline \multicolumn{7}{|l|}{ Dehulled Flour } \\
\hline Navarro & $89.6 \pm 0.0$ & $22.1 \pm 0.1$ & $2.9 \pm 0.0$ & $2.3 \pm 0.0$ & $52.6 \pm 0.2$ & - \\
\hline Dolores & $91.4 \pm 0.0$ & $26.5 \pm 0.2$ & $3.0 \pm 0.0$ & $1.9 \pm 0.0$ & $44.3 \pm 2.5$ & - \\
\hline Greenwich & $90.9 \pm 0.0$ & $21.3 \pm 0.2$ & $2.7 \pm 0.0$ & $2.5 \pm 0.0$ & $48.2 \pm 0.3$ & - \\
\hline Bluetime & $91.5 \pm 0.1$ & $22.4 \pm 0.4$ & $2.9 \pm 0.0$ & $2.2 \pm 0.0$ & $40.3 \pm 0.5$ & - \\
\hline Ostinato & $91.2 \pm 0.0$ & $25.0 \pm 0.2$ & $3.6 \pm 0.1$ & $1.9 \pm 0.0$ & $47.6 \pm 0.5$ & - \\
\hline Kalifa & $91.4 \pm 0.1$ & $24.2 \pm 0.1$ & $3.0 \pm 0.0$ & $1.9 \pm 0.0$ & $46.6 \pm 0.1$ & - \\
\hline Salamanca & $90.8 \pm 0.0$ & $22.4 \pm 0.1$ & $2.8 \pm 0.0$ & $2.0 \pm 0.0$ & $49.2 \pm 3.3$ & - \\
\hline Florida & $91.2 \pm 0.1$ & $24.8 \pm 0.1$ & $2.9 \pm 0.0$ & $2.7 \pm 0.2$ & $45.0 \pm 4.6$ & - \\
\hline RLPY 141091 & $91.3 \pm 0.1$ & $27.2 \pm 0.0$ & $2.8 \pm 0.0$ & $1.9 \pm 0.0$ & $32.5 \pm 0.8$ & - \\
\hline Orchestra & $92.2 \pm 0.1$ & $26.3 \pm 0.2$ & $3.5 \pm 0.2$ & $1.9 \pm 0.0$ & $35.8 \pm 0.3$ & - \\
\hline Astronaute & $91.2 \pm 0.0$ & $22.0 \pm 0.0$ & $2.5 \pm 0.1$ & $2.0 \pm 0.1$ & $45.3 \pm 1.1$ & - \\
\hline Croft & $91.8 \pm 0.1$ & $22.5 \pm 0.1$ & $2.6 \pm 0.0$ & $2.1 \pm 0.0$ & $48.0 \pm 2.2$ & - \\
\hline \multicolumn{7}{|l|}{ Protein Isolate } \\
\hline Navarro & $93.0 \pm 0.0$ & $83.5 \pm 0.4$ & $5.3 \pm 0.3$ & $5.9 \pm 0.0$ & - & 33.8 \\
\hline Dolores & $93.5 \pm 0.1$ & $89.5 \pm 0.2$ & $5.4 \pm 0.1$ & $4.7 \pm 0.1$ & - & 54.4 \\
\hline Greenwich & $93.8 \pm 0.0$ & $83.6 \pm 0.4$ & $6.0 \pm 0.6$ & $9.0 \pm 0.2$ & - & 34.8 \\
\hline Bluetime & $94.4 \pm 0.0$ & $84.1 \pm 0.0$ & $6.4 \pm 0.4$ & $8.4 \pm 0.3$ & - & 42.2 \\
\hline Ostinato & $94.1 \pm 0.0$ & $86.0 \pm 0.5$ & $7.6 \pm 0.4$ & $7.1 \pm 0.4$ & - & 38.6 \\
\hline Kalifa & $93.0 \pm 0.0$ & $86.9 \pm 0.9$ & $5.9 \pm 0.1$ & $7.0 \pm 0.5$ & - & 46.2 \\
\hline Salamanca & $93.7 \pm 0.6$ & $85.0 \pm 0.3$ & $6.1 \pm 1.0$ & $8.7 \pm 0.6$ & - & 42.2 \\
\hline Florida & $92.5 \pm 0.0$ & $87.4 \pm 1.1$ & $5.6 \pm 0.1$ & $7.4 \pm 0.7$ & - & 59.2 \\
\hline RLPY 141091 & $93.4 \pm 0.0$ & $90.3 \pm 0.0$ & $8.5 \pm 0.7$ & $7.3 \pm 0.8$ & - & 53.6 \\
\hline Orchestra & $92.8 \pm 0.3$ & $87.1 \pm 0.1$ & $6.7 \pm 1.1$ & $6.2 \pm 0.9$ & - & 62.2 \\
\hline Astronaute & $96.0 \pm 0.2$ & $86.4 \pm 0.1$ & $5.4 \pm 0.1$ & $7.8 \pm 0.1$ & - & 42.1 \\
\hline Croft & $92.5 \pm 0.1$ & $86.7 \pm 0.6$ & $6.2 \pm 0.1$ & $7.8 \pm 0.1$ & - & 47.3 \\
\hline
\end{tabular}

Results are expressed as means \pm standard deviations $(n=2)$. No significant differences were found among cultivars within the same column (Dunn's test with Bonferroni correction, $p<0.05)$. Note: ${ }^{*}$ based on dry matter; ${ }^{* *}$ based on protein content $(\mathrm{g}$ of protein $/ \mathrm{kg}$ of seeds).

\subsection{Molecular Weight Distribution}

Gel electrophoresis was performed under non-reducing and reducing conditions to reveal differences within the protein composition of the isolates from the different cultivars (Figure 1). The protein fractions ranged from 93 to $6.5 \mathrm{kDa}$. Three major fractions were identified in both conditions. Under non-reducing conditions, fractions around $\sim 65 \mathrm{kDa}$, $\sim 53 \mathrm{kDa}$, and $\sim 45 \mathrm{kDa}$ were most prominent, while under reducing conditions, $53 \mathrm{kDa}$ proteins were absent and the intensity of the $\sim 39 \mathrm{kDa}$ fraction increased. Bands around 86 and $91 \mathrm{kDa}$ may have been due to convicilin precursors and lipoxygenase (LOX), respectively $[16,45]$. The most visible difference between non-reducing and reducing conditions was observed for all protein isolates around the 50-56 kDa region, which might correspond to legumin $[16,18]$. Legumin consists of two polypeptides, one acid (Leg $\alpha)$ and one basic (Leg $\beta$ ) subunit, connected via disulfide bonding. These subunits were found at around 37-40 kDa for Leg $\alpha$ and 19-22 kDa for Leg $\beta$, with higher intensities under reducing conditions.

Among the different protein fractions, the allergens Pis s2 and Pis s1 were investigated in detail. Table 3 shows the protein band intensities for each of the allergen fractions. These allergens lack cysteine residues, hindering the formation of disulfide bonds [14]. For this reason, the allergen protein fractions were expected to appear under both conditions. 


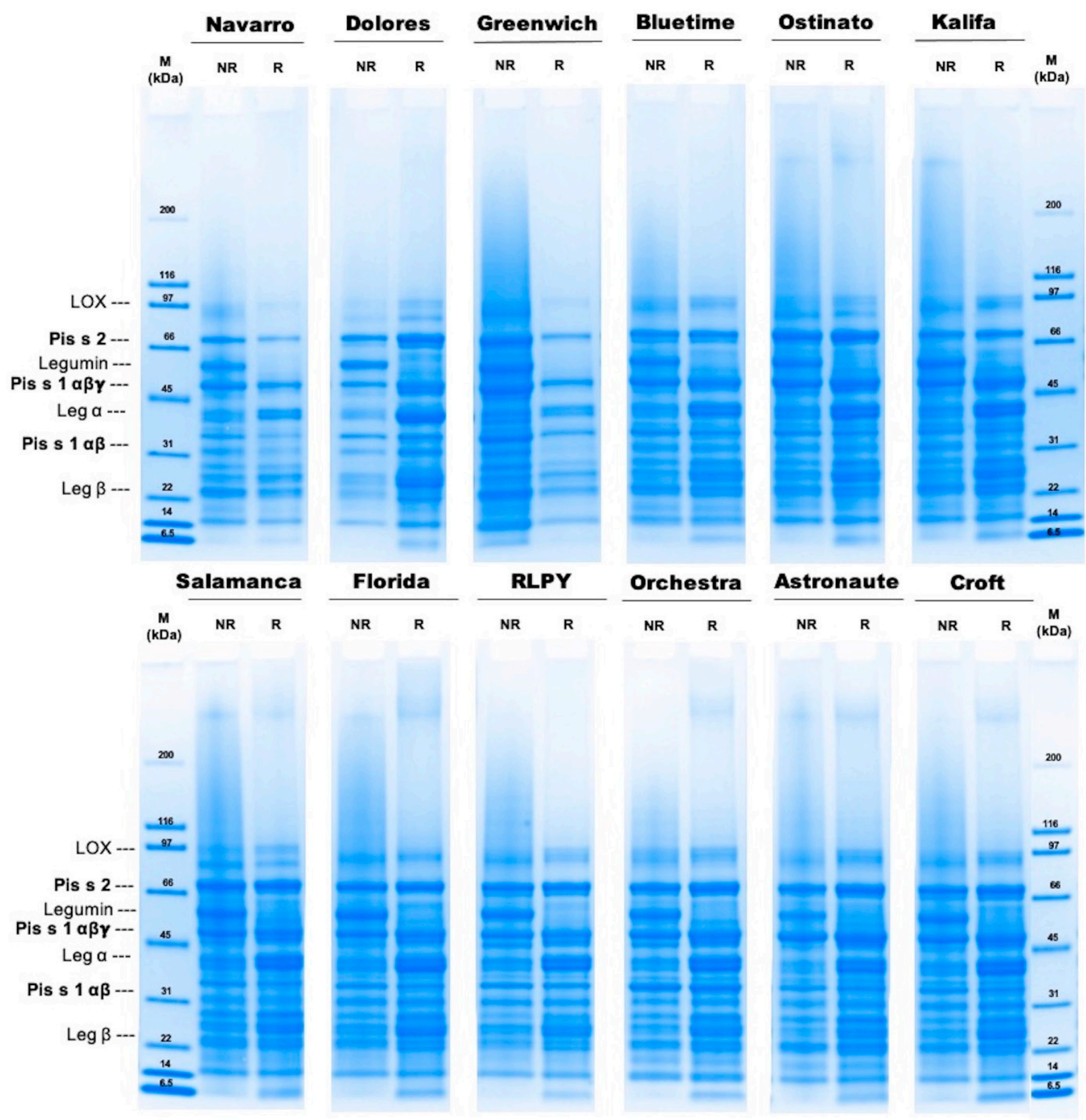

Figure 1. Molecular weight distribution of pea protein isolates from different cultivars, as determined by SDS-PAGE under non-reducing (NR) and reducing (R) conditions. Pis s2, Pis s1 $\alpha \beta \gamma$, and Pis s2 $\alpha \beta$ correspond to the allergen fractions from convicilin, mature vicilin- $\alpha \beta \gamma$, and vicilin- $\alpha \beta$, respectively. M: molecular weight standard indicated in kilodalton (kDa).

Convicilin Pis s2. The average molecular weight of the Pis s2 fraction was around $65 \mathrm{kDa}$, and values were not significantly different among the isolates. The isolate from Orchestra showed the strongest intensities under both conditions. In contrast, the Kalifa isolate and the Navarro isolate showed the lowest intensities under non-reducing and reducing conditions, respectively. The intensity of this protein fraction increased slightly under reducing conditions for all isolates, except for the Navarro and Greenwich isolates, where the intensity of the bands was slightly lower.

Vicilin Pis s1. The mature allergen fraction (vicilin- $\alpha \beta \gamma$ ) was around $45 \mathrm{kDa}$ under both conditions and was not significantly different among the isolates. Under non-reducing conditions, the Navarro isolate showed the strongest intensity. On the other hand, the RLPY and Florida isolates showed the lowest intensities. Under reducing conditions, 
vicilin- $\alpha \beta \gamma$ from Astronaute isolate showed the highest intensity, whereas the one from the Greenwich isolate showed the lowest. Vicilin- $\alpha \beta \gamma$ can go through post-translational cleavage, resulting in different fractions [46]. From these proteolytic fragments, vicilin- $\alpha \beta$ $(\sim 32 \mathrm{kDa})$ was shown to bear a high allergenic potential [23]. Besides the Orchestra isolate, all isolates showed lower intensities of the vicilin- $\alpha \beta$ fractions compared to the mature fraction and were not significantly different.

Table 3. Protein band intensities (Int) of globular protein allergens of pea protein isolates, namely convicilin (Pis s2), vicilin $\alpha \beta \gamma$ (Pis s1), and vicilin- $\alpha \beta$ (Pis s1) from different cultivars as determined by sodium dodecyl sulfate-polyacrylamide gel electrophoresis.

\begin{tabular}{|c|c|c|c|c|c|c|}
\hline \multirow[t]{3}{*}{ Cultivar } & \multicolumn{6}{|c|}{ Protein Band Intensity [Int] } \\
\hline & \multicolumn{2}{|c|}{ Convicilin Pis s2 } & \multicolumn{2}{|c|}{ Vicilin $\alpha \beta \gamma$ Pis s1 } & \multicolumn{2}{|c|}{ Vicilin $\alpha \beta$ Pis $\mathrm{s} 1$} \\
\hline & NR & $\mathbf{R}$ & NR & $\mathbf{R}$ & NR & $\mathbf{R}$ \\
\hline Navarro & $185 \pm 16$ & $146 \pm 79$ & $308 \pm 34$ & $280 \pm 73$ & $81 \pm 13$ & $95 \pm 50$ \\
\hline Dolores & $214 \pm 5$ & $367 \pm 35$ & $166 \pm 22$ & $282 \pm 43$ & $118 \pm 5$ & $97 \pm 11$ \\
\hline Greenwich & $219 \pm 47$ & $185 \pm 57$ & $229 \pm 55$ & $256 \pm 36$ & $126 \pm 16$ & $113 \pm 2$ \\
\hline Bluetime & $241 \pm 17$ & $263 \pm 49$ & $236 \pm 66$ & $311 \pm 39$ & $111 \pm 7$ & $127 \pm 9$ \\
\hline Ostinato & $253 \pm 31$ & $343 \pm 32$ & $252 \pm 66$ & $361 \pm 11$ & $105 \pm 19$ & $116 \pm 37$ \\
\hline Kalifa & $141 \pm 6$ & $205 \pm 36$ & $285 \pm 47$ & $392 \pm 46$ & $122 \pm 8$ & $153 \pm 7$ \\
\hline Salamanca & $280 \pm 2$ & $363 \pm 5$ & $233 \pm 51$ & $350 \pm 20$ & $89 \pm 3$ & $88 \pm 16$ \\
\hline Florida & $218 \pm 16$ & $283 \pm 51$ & $196 \pm 88$ & $330 \pm 60$ & $94 \pm 1$ & $72 \pm 6$ \\
\hline RLPY 141091 & $294 \pm 13$ & $379 \pm 63$ & $149 \pm 25$ & $285 \pm 78$ & $117 \pm 8$ & $106 \pm 0$ \\
\hline Orchestra & $302 \pm 50$ & $421 \pm 32$ & $212 \pm 78$ & $398 \pm 19$ & $228 \pm 38$ & $180 \pm 5$ \\
\hline Astronaute & $251 \pm 34$ & $365 \pm 44$ & $293 \pm 72$ & $411 \pm 20$ & $118 \pm 28$ & $99 \pm 8$ \\
\hline Croft & $261 \pm 55$ & $372 \pm 79$ & $235 \pm 79$ & $353 \pm 29$ & $93 \pm 7$ & $79 \pm 20$ \\
\hline
\end{tabular}

Results are expressed as means \pm standard deviations $(n=2)$. No significant differences were found among cultivars within the same column (Dunn's test with Bonferroni correction, $p<0.05$ ). NR: non reducing conditions; R: reducing conditions.

The intensities of the protein and allergen fractions can differ among legume cultivars, while the intensity of the allergen fractions specifically can give an indication of the allergenic potential $[14,18,47]$. Overall, the Orchestra isolate showed slightly stronger intensities for the potential allergen fractions compared to the other isolates, whereas the isolate from Navarro had the lowest intensities for these fractions. However, the allergen fraction intensities were not significantly different among isolates. It is known that the globulin-to-albumin and legumin-to-vicilin ratios change throughout seed development [48], which could affect the presence and intensity of potential allergens. Even under the same environment, harvesting, and storage conditions, the variation among proteins in pea cultivars can be very large [14].

\subsection{Color}

Table 4 shows the color values of the samples and the white reference. The lightness $\left(\mathrm{L}^{*}\right)$ levels among isolates were significantly different; the isolate of Orchestra cultivar showed significantly higher lightness (90.6) than the Bluetime (86.8) isolate. The Greenwich, Bluetime, and Croft isolates showed the lowest $\mathrm{a}^{*}$ values, which corresponded to their cotyledon green color; however, only the isolate from Croft was significantly different to the isolates from Salamanca and Astronaute cultivars. In contrast, the isolate from the Navarro cultivar showed higher $\mathrm{b}^{*}$ values, suggesting a stronger yellow color. The total color difference $\left(\Delta E_{a b}^{*}\right)$ allows for quantification of the colors and allows comparison between samples; the lower the $\Delta E^{*} a b$ value, the whiter the isolate is. All $\Delta E_{a b}^{*}$ values ranged between 19.2 and 23.4. According to the lowest difference from the white reference, the isolates from the Dolores and Greenwich cultivars were most white, while the isolate from Navarro cultivar was least white. 
Table 4. CIE lab color results from pea protein isolates from different cultivars and a commercial pea protein isolate.

\begin{tabular}{|c|c|c|c|c|}
\hline Cultivar & Pea Isolate CIE Color & & & \\
\hline & $L^{*}$ & $a^{*}$ & $\mathbf{b}^{*}$ & $\Delta E_{a b}^{*}$ \\
\hline Navarro & $89.3 \pm 0.4 \mathrm{ab}$ & $2.8 \pm 0.1_{\mathrm{ab}}$ & $23.7 \pm 0.2 \mathrm{a}$ & $23.4 \pm 0.2 \mathrm{a}$ \\
\hline Dolores & $88.5 \pm 0.1_{\mathrm{ab}}$ & $1.9 \pm 0.0 \mathrm{ab}$ & $19.1 \pm 0.2 \mathrm{a}$ & $19.2 \pm 0.1 \mathrm{a}$ \\
\hline Greenwich & $88.2 \pm 0.1_{\mathrm{ab}}$ & $0.6 \pm 0.1_{\mathrm{ab}}$ & $19.2 \pm 0.4_{\mathrm{a}}$ & $19.3 \pm 0.3 \mathrm{a}$ \\
\hline Bluetime & $86.8 \pm 0.3 \mathrm{a}$ & $0.9 \pm 0.1_{\mathrm{ab}}$ & $20.5 \pm 0.7 \mathrm{a}$ & $21.0 \pm 0.7 \mathrm{a}$ \\
\hline Ostinato & $89.4 \pm 0.3 \mathrm{ab}$ & $3.2 \pm 0.2 \mathrm{ab}$ & $20.5 \pm 0.4_{\mathrm{a}}$ & $20.4 \pm 0.5_{\mathrm{a}}$ \\
\hline Kalifa & $89.5 \pm 0.3 \mathrm{ab}$ & $2.8 \pm 0.0 \mathrm{ab}$ & $20.5 \pm 0.2 \mathrm{a}$ & $20.3 \pm 0.2 \mathrm{a}$ \\
\hline Salamanca & $88.3 \pm 0.2 \mathrm{ab}$ & $3.3 \pm 0.1 \mathrm{ab}$ & $21.3 \pm 0.3 \mathrm{a}$ & $21.5 \pm 0.3 \mathrm{a}$ \\
\hline Florida & $88.6 \pm 0.3 \mathrm{ab}$ & $2.7 \pm 0.2 \mathrm{ab}$ & $20.8 \pm 0.2 \mathrm{a}$ & $20.8 \pm 0.3 \mathrm{a}$ \\
\hline RLPY 141091 & $90.1 \pm 0.2 \mathrm{ab}$ & $3.1 \pm 0.1 \mathrm{ab}$ & $22.0 \pm 0.2 \mathrm{a}$ & $22.0 \pm 0.3 \mathrm{a}$ \\
\hline Orchestra & $90.6 \pm 0.6_{b}$ & $2.6 \pm 0.3 \mathrm{ab}$ & $20.9 \pm 0.4_{\mathrm{a}}$ & $20.3 \pm 0.5 \mathrm{a}$ \\
\hline Astronaute & $88.2 \pm 0.3 \mathrm{ab}$ & $3.5 \pm 0.1_{\mathrm{a}}$ & $22.8 \pm 0.3 \mathrm{a}$ & $22.9 \pm 0.3 \mathrm{a}$ \\
\hline Croft & $87.3 \pm 0.3 \mathrm{ab}$ & $-0.5 \pm 0.0_{b}$ & $19.9 \pm 0.2 \mathrm{a}$ & $20.3 \pm 0.3 \mathrm{a}$ \\
\hline
\end{tabular}

Results are expressed as means \pm standard deviations $(n=3)$. Subscripts with different letters indicate significant differences within the same column (Dunn's test with Bonferroni correction, $p<0.05$ ). Note: $\Delta E_{a b}^{*}$ : color difference compared to a white reference.

\subsection{Particle Size}

Spray drying is one of the most common methods for drying protein solutions on an industrial scale. However, protein structures are to known to be affected by spray drying due to applied temperatures, vaporization, and the air-water interface.

These effects can cause protein denaturation and further aggregation of the exposed hydrophobic regions, which can affect the particle size of the dried proteins [20]. The particle size, in turn, is known to affect the physicochemical properties of proteins $[49,50]$. The particle sizes of the PPIs, described as the average volume weighted mean $\left(\mathrm{d}_{4,3}\right)$, are shown in Table 5 . The average $\mathrm{d}_{4,3}$ of the cultivar isolates was $11.9 \mu \mathrm{m}$. Of all protein isolates, the Florida protein isolate showed the largest $\mathrm{d}_{4,3}$ at $18.8 \mu \mathrm{m}$, followed by the Dolores and Croft isolates. The isolate from RLPY showed the smallest $\mathrm{d}_{4,3}$ at $7.5 \mu \mathrm{m}$, followed by Ostinato and Astronaute isolates. The different particle sizes among the investigated cultivar isolates might lead to differences in physicochemical behavior as a result of different particle morphologies [51].

Table 5. Physicochemical and functional properties of pea protein isolates from different pea cultivars.

\begin{tabular}{|c|c|c|c|c|c|c|}
\hline \multirow[b]{2}{*}{ Cultivar } & \multirow{2}{*}{$\begin{array}{c}\text { Particle Size } \\
\mathrm{d}_{4,3}\end{array}$} & \multicolumn{2}{|c|}{ Protein Solubility ** } & \multicolumn{2}{|c|}{ Emulsifying Capacity } & \multirow{2}{*}{$\begin{array}{c}\text { Foaming Capacity } \\
\mathrm{pH} 4.5\end{array}$} \\
\hline & & $\mathrm{pH} 4.5$ & pH7.0 & $\mathrm{pH} 4.5$ & pH 7.0 & \\
\hline & {$[\mu \mathrm{m}]$} & {$[\%]$} & {$[\%]$} & {$\left[\mathrm{mL} \mathrm{g}^{-1}\right]$} & {$\left[\mathrm{mL} \mathrm{g}^{-1}\right]$} & {$[\%]$} \\
\hline Navarro & $13.19 \pm 0.56$ & $10.3 \pm 0.2$ & $51.5 \pm 0.9$ & $405 \pm 1$ & $600 \pm 7$ & $805 \pm 0$ \\
\hline Dolores & $15.81 \pm 0.06$ & $7.4 \pm 0.0$ & $60.8 \pm 2.8$ & $340 \pm 7$ & $706 \pm 14$ & $808 \pm 4$ \\
\hline Greenwich & $12.82 \pm 0.19$ & $8.8 \pm 1.3$ & $55.4 \pm 3.4$ & $396 \pm 2$ & $734 \pm 7$ & $839 \pm 36$ \\
\hline Bluetime & $9.20 \pm 0.49$ & $7.7 \pm 0.2$ & $53.8 \pm 2.4$ & $365 \pm 1$ & $710 \pm 8$ & $915 \pm 0$ \\
\hline Ostinato & $7.86 \pm 0.02$ & $8.3 \pm 1.9$ & $60.4 \pm 1.9$ & $385 \pm 14$ & $787 \pm 32$ & $959 \pm 10$ \\
\hline Kalifa & $13.55 \pm 1.53$ & $7.3 \pm 0.0$ & $40.0 \pm 2.1$ & $354 \pm 1$ & $747 \pm 3$ & $911 \pm 40$ \\
\hline Salamanca & $10.15 \pm 0.40$ & $5.9 \pm 0.6$ & $48.6 \pm 3.6$ & $378 \pm 11$ & $744 \pm 2$ & $835 \pm 0$ \\
\hline Florida & $18.84 \pm 1.31$ & $0.9 \pm 1.3$ & $41.3 \pm 7.1$ & $340 \pm 7$ & $781 \pm 23$ & $884 \pm 14$ \\
\hline RLPY 141091 & $7.53 \pm 0.01$ & $2.3 \pm 0.6$ & $52.6 \pm 2.8$ & $359 \pm 5$ & $835 \pm 7$ & $874 \pm 13$ \\
\hline Orchestra & $11.31 \pm 0.21$ & $1.5 \pm 0.0$ & $61.8 \pm 6.0$ & $366 \pm 1$ & $790 \pm 6$ & $835 \pm 9$ \\
\hline Astronaute & $7.94 \pm 0.29$ & $6.3 \pm 0.3$ & $52.4 \pm 0.9$ & $381 \pm 7$ & $681 \pm 23$ & $858 \pm 23$ \\
\hline Croft & $14.66 \pm 1.35$ & $0.0 \pm 0.0$ & $43.6 \pm 5.1$ & $355 \pm 0$ & $790 \pm 24$ & $861 \pm 6$ \\
\hline
\end{tabular}

Results are expressed as means \pm standard deviations. No significant differences were found among cultivars within the same column (Dunn's test with Bonferroni correction, $p<0.05$ ). The particle size was based on Mie's theory (RI1.33). Note: $\mathrm{d}_{4,3}$ : volume weighted mean; ** based on protein content. 


\subsection{Functional Properties}

High functional properties of PPIs are desired to increase their usage as ingredients in different plant-based food products. Table 5 shows the results of the functional properties.

\subsubsection{Protein Solubility}

At $\mathrm{pH} 4.5$, the Navarro isolate showed the highest protein solubility at $10.3 \%$, which was different to the isolate from Florida $(0.9 \%)$, Orchestra $(1.5 \%)$, and Croft $(0.0 \%)$ cultivars. On the other hand, at $\mathrm{pH} 7.0$, the Orchestra isolate showed the highest protein solubility $(61.8 \%)$, followed by the Dolores $(60.8 \%)$ and Ostinato $(60.4 \%)$ isolates. Overall, the protein solubility levels at $\mathrm{pH} 7$ were similar among the isolates. Other studies have shown similar solubilities or even values up to $80 \%$ at $\mathrm{pH} 7.0$ [17-19]. The protein solubility level is related to extraction and drying methods; for example, isolates obtained after alkaline extraction and isoelectric precipitation have lower solubility than those obtained after saltinduced extraction [17]. Moreover, in contrast to lyophilization used in previous studies, spray drying leads to higher protein denaturation, increasing hydrophobic protein-protein interactions, and thus reducing overall protein solubility [52]. High protein solubility levels are, however, essential for beverage and dairy-alternative applications; treatments such

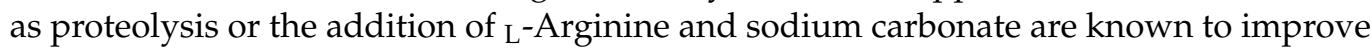
protein solubilities of PPIs [22,35].

\subsubsection{Emulsifying Capacity}

The isolate from Navarro showed the highest emulsifying capacity at $\mathrm{pH} 4.5$ with $405 \mathrm{~mL} \mathrm{~g}^{-1}$, while the one from Dolores and Florida showed the lowest. There were significant moderate correlations between the emulsifying capacity at $\mathrm{pH} 4.5$ and both the protein solubility at $\mathrm{pH} 4.5(\mathrm{r}=0.50)$ and the protein content $(\mathrm{r}=-63)$. On the other hand, the emulsifying capacity at $\mathrm{pH} 7.0$ showed a significant positive moderate correlation with the protein content $(\mathrm{r}=0.45)$. Thus, at neutral $\mathrm{pH}$, the RLPY isolate showed the highest emulsifying capacity at $835 \mathrm{~mL} \mathrm{~g}^{-1}$ and was highly different from the isolates from Navarro and Astronaute cultivars. Hydrophobic residues are essential to facilitate protein oil interactions [53], however a high number of protein-protein interactions would form aggregates hiding hydrophobic residues, thus hindering the ability to interact with oil. These aggregates might be formed during spray drying, thus increasing particle size. However, no significant correlations were found between the emulsifying capacity and the particle size. Moreover, the vicilin/legumin ratio plays an important role in the formation of emulsions; Barac and Cabrilo [18] showed that the lower the ratio is, the higher the emulsifying capacity of the isolate, especially at neutral $\mathrm{pH}$ ranges. Although electrophoretic results showed no significant differences among allergens or overall in the electrophoretic patterns, further quantification of the fractions might be necessary to determine correlations with the functional properties.

\subsubsection{Foaming Capacity}

At $\mathrm{pH} 7.0$ no foam formation was observed, whereas at $\mathrm{pH} 4.5$ all isolates showed an average foaming capacity of $866 \%$. These results are in contrast to the results of Chao and Aluko [54], who obtained higher foaming capacities the further the $\mathrm{pH}$ moved away from the isoelectric point. On the other hand, Gharsallaoui and Cases [55] suggested that close to the isoelectric point ( $\mathrm{pH}$ 4.5), pea globulins are more surface-active and a reduction in the electrostatic charge of the protein molecules might result in electrostatic repulsion, in turn increasing adsorption. The latter is important for the formation of foam [56] and might explain the foaming capacity at $\mathrm{pH} 4.5$ for the cultivars investigated in this study. Another explanation is that the fat content in the PPIs might have acted as an antifoam agent. In order to destroy a foam film, the hydrophobic particle droplets that emerge from the aqueous phase into the air-water interface are critical [57]. At $\mathrm{pH} 7$, the hydrophobic protein surfaces facilitate the entrance of the fat droplets, leading to defoaming. At $\mathrm{pH} 4.5$, 
the hydrophobic side chains of the proteins are hidden, hindering the penetration of the fat droplets in the foam films.

A principal component analysis (PCA) was applied to analyze the relationships among the different cultivars and their colors, protein and fat contents, particle sizes, and physicochemical properties. Figure 2A shows a biplot of principal component (PC) 1 and PC2 using the standardized scores for the isolates. The first two components of the PCA explained $57.13 \%$ of the total variance. The protein content $(-0.44)$ and emulsifying capacity at $\mathrm{pH}$ 4.5 (0.51) had the strongest influence on PC1. On the other hand, the fat content (0.58) and foaming capacity (0.54) had the strongest influence on PC2; moreover, on the negative quadrant of the PC2, the particle size showed a strong influence $(-0.41)$.

The isolate from Navarro cultivar scored the highest for PC1 (1.93), opposite to the isolates from Kalifa, RLPY, and Croft. This is in agreement with the emulsifying capacities shown in Section 3.5. Furthermore, the Dolores isolate scored the highest in the PC2 $(-2.30)$, followed by Navarro $(-1.51)$, as they showed lower fat contents among the isolates. Negative moderate correlations were found between the protein content and the protein solubility ( $\mathrm{pH} 4.5$ ) and emulsifying capacity ( $\mathrm{pH} 4.5)$. On the other hand, the protein content was significantly positive and moderately correlated with the emulsifying capacity at $\mathrm{pH}$ 7.0. The particle size showed no significant correlations to other investigated attributes. When replacing a raw material in an existing product, not only are the composition and functionality important, but the color should be also considered, as it can affect the perception of the product by the consumer; for this reason, the $\Delta E_{a b}^{*}$ of the isolates was included in the PCA. However, the $\Delta E^{*}$ ab showed low influence on any of the components.

The PCA shows two clusters plus two outliers. The isolates from RLPY, Croft, Kalifa, Florida, and Orchestra cultivars formed the first cluster; on the opposite side, isolates from Ostinato, Bluetime, Salamanca, Astronaute, and Greenwich cultivars formed the second cluster. These clusters suggest that the physicochemical characteristics are probably more similar and one cultivar could be replaced with another from the same cluster. On the other hand, the isolates from Navarro and Dolores were found to be further away from all other isolates, which might hinder the replacement of these cultivars. Moreover, the isolates should be chosen by considering the requirements of the final products. For example, the RLPY isolate could be used in applications with neutral $\mathrm{pH}$, such as dairy alternatives, as it is plotted as having higher protein content, high emulsifying capacity ( $\mathrm{pH}$ 7.0), and moderate protein solubility ( $\mathrm{pH}$ 7.0); however, its application at low $\mathrm{pH}$ values is inappropriate due to its lower protein functionality. On the other hand, the Navarro isolate might be better suited in applications with acidic $\mathrm{pH}$ values, such as in plant-based mayonnaise.

\subsection{Sensory Analysis}

A principal component analysis was applied to analyze relationships between samples and retronasal aroma attributes and taste profiles (Figure 2B). PC1 and PC2 represented $66.03 \%$ of the total variance; the following values represent the coefficient values (influence) of the attributes and the scores of the isolates from each cultivar. 


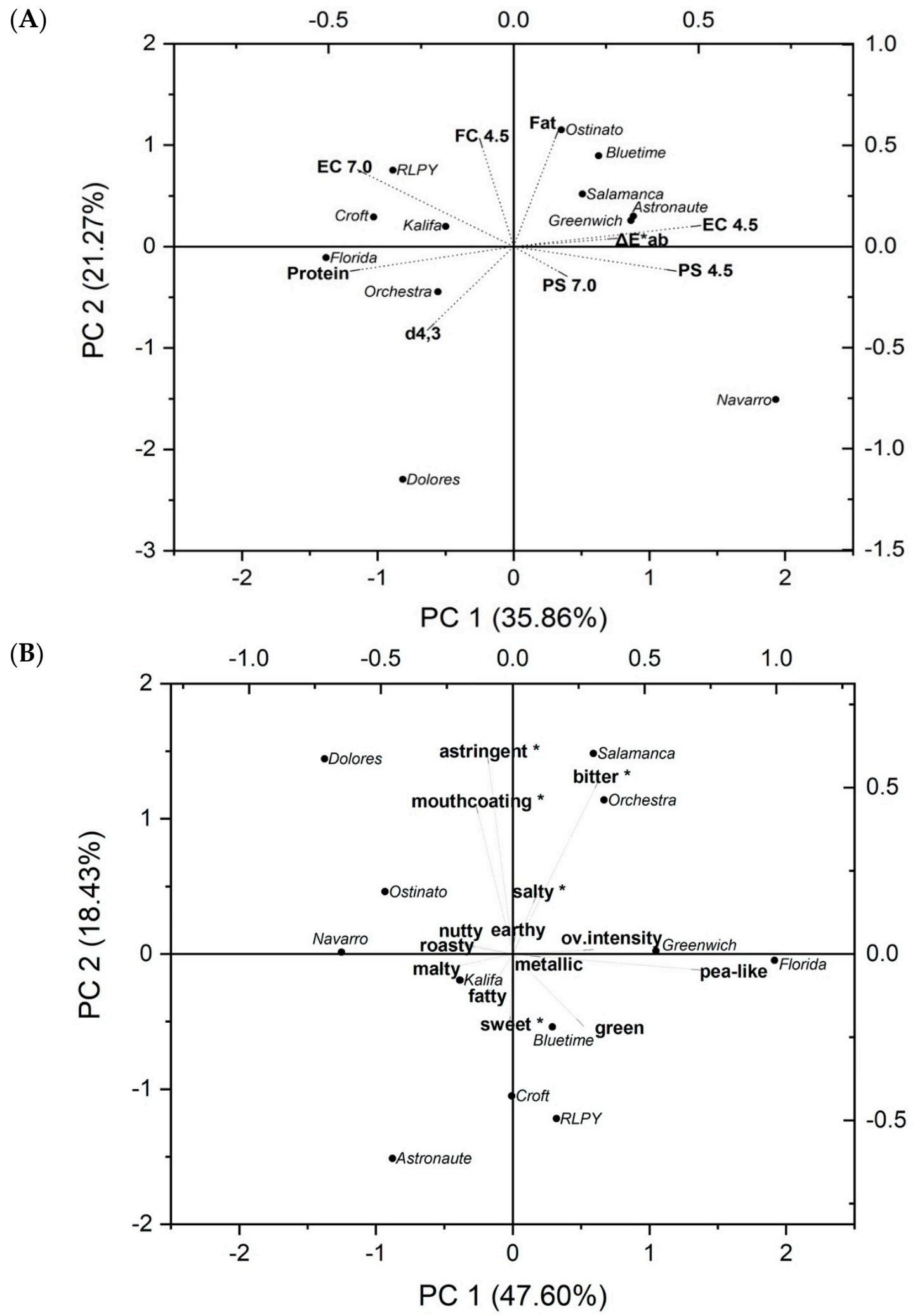

Figure 2. Biplot of (A) physicochemical properties and (B) sensory profiles of pea protein isolates from different pea cultivars. Attributes with an asterisk $\left(^{*}\right)$ refer to taste. PS: protein solubility; EC: emulsifying capacity; FC: foaming capacity; $\Delta \mathrm{E}_{\mathrm{ab}}^{*}$ : color difference compared to a white reference; $\mathrm{d}_{4,3}$ : particle size. The numbers represent the $\mathrm{pH}(7.0$ or 4.5$)$ in which the analysis was performed. 
Aroma. According to a one-way ANOVA, pea-like was the only aroma attribute with a significant difference among isolates and showed the strongest influence on PC1 (0.71), followed by malty $(-0.30)$ and green $(0.27)$ aromas. For PC2, the green aroma showed the strongest influence among all aroma attributes $(-0.22)$. The metallic, earthy, roasty, and nutty attributes showed almost no influence on any of the components. The isolates from Dolores $(-1.38)$ and Navarro $(-1.25)$ scored the lowest for PC1, which suggests these isolates were perceived to have the least pea-like aroma. In contrast, Florida (1.92) and Greenwich (1.05) isolates scored the highest for this component, indicating a stronger pealike aroma. The pea-like aroma is known to be well-perceived because of the low thresholds of 2-isopropyl-3-methoxypyrazine [58], which might explain its strong influence. The PCA showed the isolates from Greenwich, Florida, RLPY, and Croft cultivars as being closer to the green attribute, in agreement with the results from the sensory analysis. The green aroma originating from hexanal is a characteristic oxidation product of fatty acids, in particular of linoleic and linolenic acids catalyzed by LOX [44]. Higher activity of this enzyme could increase the green aroma perception; however, there was only a moderate negative correlation $(\mathrm{r}=-0.54)$ between the green aroma and the LOX band intensities under reduction conditions. Although it has also been mentioned that green cultivars have higher levels of hexanal [8], there was no significant correlation between the $\mathrm{a}^{*}$ color and green aroma.

Environmental and genetic conditions might affect the production and degradation rates of the aroma compounds, which would result in higher or lower aroma perceptions [8,59]. Using HC/MS analysis, Azarnia and Boye [8] found that the concentrations of volatile compounds depended on the cultivar, crop year, storage, and processing conditions. Specific processing methods such as enzymatic treatment or fermentation might be useful to reduce some of the characteristic off-flavors of pea isolates. However, other aroma compounds might be generated or enhanced and might further increase or decrease consumer acceptance $[4,60,61]$. Furthermore, methoxypyrazines are very stable during fermentation due to their chemical nature, and therefore are very difficult to remove or reduce [62]. Therefore, pea cultivars low in pea-like aroma, such as from Dolores or Navarro, are recommended to be used for production of PPIs with sensory appeal.

Taste. The bitter attribute was the only significant taste attribute according to one-way ANOVA. The bitter (0.53) and astringent (0.60) tastes had the strongest influence on PC2. As shown in the PCA, the PPIs from Salamanca and Orchestra scored highest for bitter taste. In contrast, the PPI from Astronaute scored lowest for bitter taste and was significantly less bitter than the PPI from Salamanca. The Dolores isolate scored the highest for astringent taste, together with Salamanca and Orchestra isolates. Moreover, salty and sweet tastes had little influence on either component, which suggests that the intensity of these tastes was lower and similar among the samples. A high bitter taste for a PPI might hinder its application in food products; thus, several methods have been investigated to reduce the bitterness of legume protein isolates [61,63].

Overall Intensity. The isolate from Florida cultivar showed the highest overall intensity, whereas the isolate from Dolores showed the lowest intensity. However, the overall intensity levels among the PPIs were not significantly different. The overall intensity was moderately correlated with the pea-like $(\mathrm{r}=0.66)$, green $(\mathrm{r}=0.43)$, and malty $(\mathrm{r}=-0.47)$ aroma, which suggests that these compounds were characteristic of the isolates, as mentioned previously in the aroma section.

\section{Conclusions}

Peas are a valuable source of protein and are increasingly used in plant-based products; however, due to the large number of different cultivars, most of them have not been characterized regarding their chemical composition, functional properties, and sensory profiles. In this study, all these aspects were investigated for 12 cultivars grown in Germany and France. 
Our study shows that the chemical composition of flour and isolates from the cultivars are slightly different. The main allergen fractions were present in all the PPI and showed no significant differences. The PCA showed two cluster of cultivars regarding the physicochemical and functional characteristics; however, these clusters were not found in the sensory profile PCA. This suggests that although some isolates could be substituted interchangeably for the same products with regard to their similar functionalities, the flavor of these products could be affected. However, only the pea-like and bitter aromas were significantly different among isolates. The cultivars Salamanca and Astronaute are the most used cultivars in Germany; they showed similarities according to the physicochemicalfunctional PCA cluster; however, Salamanca isolates had a significant higher bitter taste and slightly higher pea-like aroma than Astronaute. These differences should be considered for targeted product developments as they might influence the acceptance by consumers. The usage of cultivars such as Navarro and Dolores should be carefully considered, as their isolates are mostly different to the other cultivars investigated in the present study.

The obtained PPI might be used in the food industry, especially under neutral conditions ( $\mathrm{pH}$ 7.0), except when foaming is required; however, when designing a food product in the acidic range at $\mathrm{pH} 4.5$, the specific selection of a suitable cultivar might be more important. Differences with laboratory and commercial processing of PPI should be considered; although spray drying was used in this study, larger spray-dryers may affect the physicochemical, functional and sensory properties of the isolates. The results of this study highlighted the importance of a tailored selection of cultivars for protein extraction as well as the suitability of pea cultivars for specific food applications.

Author Contributions: V.G.A.: conceptualization, methodology, investigation, formal analysis, writing-original draft, review and editing; S.K.: investigation; M.S.: investigation, review and editing; I.M.: methodology, writing-review and editing, supervision; U.S.-W.: resources, review and editing, supervision; P.E.: resources, review and editing, supervision. All authors have read and agreed to the published version of the manuscript.

Funding: This work was supported by the Fraunhofer Future Foundation, Germany.

Informed Consent Statement: Informed consent was obtained from all subjects involved in the sensory analysis.

Data Availability Statement: Raw data are available as Mendeley Data doi:10.17632/ywpjs6h3jr.1.

Acknowledgments: The authors thank Sigrid Gruppe and Eva Müller for their valuable contribution. We also thank Andrea Strube and Thorsten Tybussek for their constructive criticism of the manuscript. We greatly appreciate the sensory panel of the Fraunhofer Institute for Process Engineering and Packaging, Freising, Germany, for the sensory evaluation.

Conflicts of Interest: The authors declare no conflict of interest.

\section{References}

1. FAOSTAT. Crops Production. Available online: http://www.fao.org/faostat/en/\#data/QC (accessed on 11 January 2021).

2. Kreplak, J.; Madoui, M.-A.; Cápal, P.; Novák, P.; Labadie, K.; Aubert, G.; Bayer, P.E.; Gali, K.K.; Syme, R.A.; Main, D.; et al. A reference genome for pea provides insight into legume genome evolution. Nat. Genet. 2019, 51, 1411-1422. [CrossRef]

3. Jain, S.; Kumar, A.; Mamidi, S.; McPhee, K. Genetic Diversity and Population Structure Among Pea (Pisum sativum L.) Cultivars as Revealed by Simple Sequence Repeat and Novel Genic Markers. Mol. Biotechnol. 2014, 56, 925-938. [CrossRef]

4. Tulbek, M.C.; Lam, R.S.H.; Wang, Y.; Asavajaru, P.; Lam, A. Chapter 9-Pea: A Sustainable Vegetable Protein Crop. In Sustainable Protein Sources; Nadathur, S.R., Wanasundara, J.P.D., Scanlin, L., Eds.; Academic Press: San Diego, CA, USA, 2017 ; pp. 145-164. [CrossRef]

5. Vidal-Valverde, C.; Frias, J.; Hernández, A.; Martín-Alvarez, P.J.; Sierra, I.; Rodríguez, C.; Blazquez, I.; Vicente, G. Assessment of nutritional compounds and antinutritional factors in pea (Pisum sativum) seeds. J. Sci. Food Agric. 2003, 83, 298-306. [CrossRef]

6. Nikolopoulou, D.; Grigorakis, K.; Stasini, M.; Alexis, M.N.; Iliadis, K. Differences in chemical composition of field pea (Pisum sativum) cultivars: Effects of cultivation area and year. Food Chem. 2007, 103, 847-852. [CrossRef]

7. Al-Karaki, G.; Ereifej, K. Relationships between Seed Yield and Chemical Composition of Field Peas Grown under Semi-arid Mediterranean Conditions. J. Agron. Crop Sci. 2001, 182, 279-284. [CrossRef] 
8. Azarnia, S.; Boye, J.I.; Warkentin, T.; Malcolmson, L.; Sabik, H.; Bellido, A.S. Volatile flavour profile changes in selected field pea cultivars as affected by crop year and processing. Food Chem. 2011, 124, 326-335. [CrossRef]

9. Cui, L.; Kimmel, J.; Zhou, L.; Rao, J.; Chen, B. Identification of extraction $\mathrm{pH}$ and cultivar associated aromatic compound changes in spray dried pea protein isolate using untargeted and targeted metabolomic approaches. J. Agric. Food Res. 2020, $2,100032$. [CrossRef]

10. Kniskern, M.A.; Johnston, C.S. Protein dietary reference intakes may be inadequate for vegetarians if low amounts of animal protein are consumed. Nutrition 2011, 27, 727-730. [CrossRef]

11. Ahuja, K.; Mamtani, K. Pea Protein Market Share Forcasts 2020-2026; GMI362; Global Market Insights: Selbyville, DE, USA, 2020; p. 180.

12. Koyoro, H.; Powers, J.R. Functional properties of pea globulin fractions. Cereal Chem. 1987, 64, 97-101.

13. Gueguen, J.; Barbot, J. Quantitative and qualitative variability of pea (Pisum sativum L.) protein composition. J. Sci. Food Agric. 1988, 42, 209-224. [CrossRef]

14. Tzitzikas, E.N.; Vincken, J.P.; de Groot, J.; Gruppen, H.; Visser, R.G. Genetic variation in pea seed globulin composition. J. Agric. Food Chem. 2006, 54, 425-433. [CrossRef] [PubMed]

15. Casey, R.; Domoney, C. Pea Globulins. In Seed Proteins; Shewry, P.R., Casey, R., Eds.; Springer: Dordrecht, The Netherlands, 1999; pp. 171-208. [CrossRef]

16. Bourgeois, M.; Jacquin, F.; Savois, V.; Sommerer, N.; Labas, V.; Henry, C.; Burstin, J. Dissecting the proteome of pea mature seeds reveals the phenotypic plasticity of seed protein composition. Proteomics 2009, 9, 254-271. [CrossRef] [PubMed]

17. Stone, A.K.; Karalash, A.; Tyler, R.T.; Warkentin, T.D.; Nickerson, M.T. Functional attributes of pea protein isolates prepared using different extraction methods and cultivars. Food Res. Int. 2015, 76, 31-38. [CrossRef]

18. Barac, M.; Cabrilo, S.; Pesic, M.; Stanojevic, S.; Zilic, S.; Macej, O.; Ristic, N. Profile and functional properties of seed proteins from six pea (Pisum sativum) genotypes. Int. J. Mol. Sci. 2010, 11, 4973-4990. [CrossRef] [PubMed]

19. Tanger, C.; Engel, J.; Kulozik, U. Influence of extraction conditions on the conformational alteration of pea protein extracted from pea flour. Food Hydrocoll. 2020, 107, 105949. [CrossRef]

20. Haque, M.A.; Adhikari, B. Drying and Denaturation of Proteins in Spray Drying Process. In Handbook of Industrial Drying, 4th ed.; CRC Press; Taylor and Francis Group: Boca Raton, FL, USA, 2014; Volume 49, pp. 971-984.

21. LfL. Bayerische Landesanstalt für Landwirtschaft. Available online: https://www.lfl.bayern.de/ipz/oelfruechte/066649/index. php (accessed on 11 January 2021).

22. Reinkensmeier, A.; Bußler, S.; Schlüter, O.; Rohn, S.; Rawel, H.M. Characterization of individual proteins in pea protein isolates and air classified samples. Food Res. Int. 2015, 76, 160-167. [CrossRef]

23. Sanchez-Monge, R.; Lopez-Torrejon, G.; Pascual, C.Y.; Varela, J.; Martin-Esteban, M.; Salcedo, G. Vicilin and convicilin are potential major allergens from pea. Clin. Exp. Allergy 2004, 34, 1747-1753. [CrossRef] [PubMed]

24. Dreyer, L.; Astier, C.; Dano, D.; Hosotte, M.; Jarlot-Chevaux, S.; Sergeant, P.; Kanny, G. Consommation croissante d'aliments contenant du pois jaune: Un risque d'allergie? Rev. Fr. Allergol. 2014, 54, 20-26. [CrossRef]

25. Codreanu-Morel, F.; Morisset, M.; Cordebar, V.; Larré, C.; Denery-Papini, S. L'allergie au pois. Rev. Fr. Allergol. 2019, 59, 162-165. [CrossRef]

26. Tian, S.J.; Kyle, W.S.A.; Small, D.M. Pilot scale isolation of proteins from field peas (Pisum sativum L.) for use as food ingredients. Int. J. Food Sci. Technol. 1999, 34, 33-39. [CrossRef]

27. AOACa. Method 923.03. Ash of flour. In Official Methods of Analysis of the Association of Official Analytical Chemists (AOAC); Horwitz, W.A., Ed.; AOAC International: Gaithersburg, MD, USA, 2003.

28. AOACb. Method 968.06. Protein (crude) in animal feed. In Official Methods of Analysis of the Association of Official Analytical Chemists (AOAC); Horwitz, W.A., Ed.; AOAC International: Gaithersburg, MD, USA, 2003.

29. Gertz, C.; Fiebig, H.-J. Determination of fat content by the Caviezel ${ }^{\circledR}$ method (rapid method). Eur. J. Lipid Sci. Technol. 2000, 102, 154-158. [CrossRef]

30. Laemmli, U.K. Cleavage of structural proteins during assembly of head of bacteriophage-T4. Nature 1970, 227, 680-685. [CrossRef]

31. Morr, C.V.; German, B.; Kinsella, J.E.; Regenstein, J.M.; Vanburen, J.P.; Kilara, A.; Lewis, B.A.; Mangino, M.E. A collaborative study to develop a standarized food protein solubility procedure. J. Food Sci. 1985, 50, 1715-1718. [CrossRef]

32. AACC Method 46-15.01 Crude Protein-5-Minute Biuret Method for Wheat and Other Grains. Available online: https://methods. aaccnet.org/summaries/46-15-01.aspx (accessed on 1 April 2021).

33. Phillips, L.G.; Haque, Z.; Kinsella, J.E. A Method for the Measurement of Foam Formation and Stability. J. Food Sci. 1987, 52, 1074-1077. [CrossRef]

34. Wang, C.; Johnson, L.A. Functional properties of hydrothermally cooked soy protein products. J. Am. Oil Chem. Soc. 2001, 78, 189-195. [CrossRef]

35. García Arteaga, V.; Apéstegui Guardia, M.; Muranyi, I.; Eisner, P.; Schweiggert-Weisz, U. Effect of enzymatic hydrolysis on molecular weight distribution, techno-functional properties and sensory perception of pea protein isolates. Innov. Food Sci. Emerg. Technol. 2020, 65, 102449. [CrossRef]

36. García Arteaga, V.; Kraus, S.; Schott, M.; Muranyi, I.; Schweiggert-Weisz, U.; Eisner, P. Screening of Twelve Pea (Pisum sativum L.) Cultivars and its Isolates. Mendeley Data 2021, V2. [CrossRef] 
37. Shen, S.; Hou, H.; Ding, C.; Bing, D.-J.; Lu, Z.-X.; Navabi, A. Protein content correlates with starch morphology, composition and physicochemical properties in field peas. Can. J. Plant Sci. 2016, 96, 404-412. [CrossRef]

38. Maury, M.; Murphy, K.; Kumar, S.; Shi, L.; Lee, G. Effects of process variables on the powder yield of spray-dried trehalose on a laboratory spray-dryer. Eur. J. Pharm. Biopharm. 2005, 59, 565-573. [CrossRef]

39. Sosnik, A.; Seremeta, K.P. Advantages and challenges of the spray-drying technology for the production of pure drug particles and drug-loaded polymeric carriers. Adv. Colloid Interface Sci. 2015, 223, 40-54. [CrossRef]

40. Zbicinski, I. Modeling and Scaling Up of Industrial Spray Dryers: A Review. J. Chem. Eng. Jpn. 2017, 50, 757-767. [CrossRef]

41. Gao, Z.; Shen, P.; Lan, Y.; Cui, L.; Ohm, J.-B.; Chen, B.; Rao, J. Effect of alkaline extraction pH on structure properties, solubility, and beany flavor of yellow pea protein isolate. Food Res. Int. 2020, 131, 109045. [CrossRef]

42. Sternberg, M.J.E.; Thornton, J.M. On the conformation of proteins: Hydrophobic ordering of strands in $\beta$-pleated sheets. J. Mol. Biol. 1977, 115, 1-17. [CrossRef]

43. Sumner, A.K.; Nielsen, M.A.; Youngs, C.G. Production and Evaluation of Pea Protein Isolate. J. Food Sci. 1981, 46, 364-366. [CrossRef]

44. Shi, Y.; Mandal, R.; Singh, A.; Pratap Singh, A. Legume lipoxygenase: Strategies for application in food industry. Legume Sci. 2020, 2, e44. [CrossRef]

45. The UniProt Consortium. UniProt: The universal protein knowledgebase. Nucleic Acids Res. 2016, 45, D158-D169. [CrossRef]

46. Gatehouse, J.A.; Lycett, G.W.; Croy, R.R.; Boulter, D. The post-translational proteolysis of the subunits of vicilin from pea (Pisum sativum L.). Biochem. J. 1982, 207, 629-632. [CrossRef] [PubMed]

47. McClain, S.; Stevenson, S.E.; Brownie, C.; Herouet-Guicheney, C.; Herman, R.A.; Ladics, G.S.; Privalle, L.; Ward, J.M.; Doerrer, N.; Thelen, J.J. Variation in Seed Allergen Content From Three Varieties of Soybean Cultivated in Nine Different Locations in Iowa, Illinois, and Indiana. Front. Plant Sci. 2018, 9, 1025. [CrossRef] [PubMed]

48. Lam, A.C.Y.; Karaca, A.C.; Tyler, R.T.; Nickerson, M.T. Pea protein isolates: Structure, extraction, and functionality. Food Rev. Int. 2016, 34, 126-147. [CrossRef]

49. Zhao, X.; Sun, L.; Zhang, X.; Liu, H.; Zhu, Y. Effects of ultrafine grinding time on the functional and flavor properties of soybean protein isolate. Colloids Surf. B Biointerfaces 2020, 196, 111345. [CrossRef]

50. Kerr, W.L.; Ward, C.D.W.; McWatters, K.H.; Resurreccion, A.V.A. Effect of Milling and Particle Size on Functionality and Physicochemical Properties of Cowpea Flour. Cereal Chem. 2000, 77, 213-219. [CrossRef]

51. Vicente, J.; Pinto, J.; Menezes, J.; Gaspar, F. Fundamental analysis of particle formation in spray drying. Powder Technol. 2013, 247, 1-7. [CrossRef]

52. Taherian, A.R.; Mondor, M.; Labranche, J.; Drolet, H.; Ippersiel, D.; Lamarche, F. Comparative study of functional properties of commercial and membrane processed yellow pea protein isolates. Food Res. Int. 2011, 44, 2505-2514. [CrossRef]

53. Adebiyi, A.P.; Aluko, R.E. Functional properties of protein fractions obtained from commercial yellow field pea (Pisum sativum L.) seed protein isolate. Food Chem. 2011, 128, 902-908. [CrossRef]

54. Chao, D.F.; Aluko, R.E. Modification of the structural, emulsifying, and foaming properties of an isolated pea protein by thermal pretreatment. CyTA J. Food 2018, 16, 357-366. [CrossRef]

55. Gharsallaoui, A.; Cases, E.; Chambin, O.; Saurel, R. Interfacial and Emulsifying Characteristics of Acid-treated Pea Protein. Food Biophys. 2009, 4, 273-280. [CrossRef]

56. Dickinson, E. Protein Adsorption at Liquid Interfaces and the Relationship to Foam Stability. In Foams: Physics, Chemistry and Structure; Springer: London, UK, 1989; pp. 39-53. [CrossRef]

57. Denkov, N.; Marinova, K.; Denkov, N.; Marinova, K. Chapter 10—Antifoam effects of solid particles, oil drops and oil-solid compounds in aqueous foams. In Colloidal Particles at Liquid Interfaces; Binks, B.P., Horozov, T.S., Eds.; Cambridge University Press: Cambridge, UK, 2006; pp. 383-444. [CrossRef]

58. Murray, K.E.; Whitfield, F.B. The occurrence of 3-alkyl-2-methoxypyrazines in raw vegetables. J. Sci. Food Agric. 1975, 26, 973-986. [CrossRef]

59. Murat, C.; Bard, M.-H.; Dhalleine, C.; Cayot, N. Characterisation of odour active compounds along extraction process from pea flour to pea protein extract. Food Res. Int. 2013, 53, 31-41. [CrossRef]

60. Heng, L. Flavour Aspects of Pea and Its Protein Preparations in Relation to Novel Protein Foods; Wageningen University: Wageningen, The Netherlands, 2005.

61. García Arteaga, V.; Leffler, S.; Muranyi, I.; Eisner, P.; Schweiggert-Weisz, U. Sensory profile, functional properties and molecular weight distribution of fermented pea protein isolate. Curr. Res. Food Sci. 2021, 4, 1-10. [CrossRef] [PubMed]

62. Reynolds, A.G. 11-Viticultural and vineyard management practices and their effects on grape and wine quality. In Managing Wine Quality; Reynolds, A.G., Ed.; Woodhead Publishing: Cambridge, UK, 2010; pp. 365-444. [CrossRef]

63. Schlegel, K.; Leidigkeit, A.; Eisner, P.; Schweiggert-Weisz, U. Technofunctional and Sensory Properties of Fermented Lupin Protein Isolates. Foods 2019, 8, 678. [CrossRef] 